\title{
Water quality assessment of a neotropical pampean lowland stream using a phytoplankton functional trait approach
}

\author{
Diego Frau (D) - Jonathan Medrano • Claudia Calvi • \\ Adonis Giorgi
}

Received: 17 April 2019 /Accepted: 29 September 2019/Published online: 27 October 2019

(C) Springer Nature Switzerland AG 2019

\begin{abstract}
The aim of this study was to test whether the water quality phytoplankton assemblage index adapted for rivers (Qr index) is useful to characterize the water quality of a neotropical stream. We were interested also in inferring the main pollutants through a phytoplankton functional trait characterization and assessing the phytoplankton groups which may influence the Qr index final estimations. Monthly sampling of environmental variables and phytoplankton were done in three sites (S1, S2, and S3). Phytoplankton was classified according to Reynolds Functional Groups (RFG) and water quality estimation was performed using the Qr index.
\end{abstract}

Electronic supplementary material The online version of this article (https://doi.org/10.1007/s10661-019-7849-6) contains supplementary material, which is available to authorized users.

D. Frau $(\bowtie)$

Laboratorio de Plancton, Instituto Nacional de Limnología (CONICET-UNL), Ciudad Universitaria Paraje El Pozo S/N, Santa Fe, Argentina

e-mail: diegofrau@gmail.com

J. Medrano

Facultad de Ciencias y Tecnología, Universidad Autónoma de Entre Ríos, Ruta Provincial No. 11. Km 10.5, Oro Verde, Argentina

C. Calvi

Facultad de Humanidades y Ciencias, Universidad Nacional del Litoral, Ciudad Universitaria Paraje El Pozo S/N, Santa Fe, Argentina

\section{A. Giorgi}

Departamento de Ciencias Básicas (INEDES, UNLu-CONICET), Universidad Nacional de Luján, Luján, Argentina
Principal coordinates (PCO) and PERMANOVA were applied to identify the main pollutants through the RFG. RFG linkage to Qr values was assessed by general linear models (GLM). "Moderate" water quality was found in S1 the whole year, in all sampling stations during the winter, and in summer-autumn in S2. "Regular" water quality was found in S3 during the summer-autumn, and S2-S3 during the spring. S1 and S2 showed eutrophic, standing, or mix waters whereas S3 had high organic matter content and eutrophic conditions. Despite some RFG ( $\mathbf{X}_{\mathbf{1}}$ and $\mathbf{M P}$ ) being linked to high Qr values and some other ( $\mathbf{M}, \mathbf{S 1}$ and $\mathbf{Z}$ ) to low, their dominance did not influence water quality estimation performed by the Qr. We conclude that the Qr index was useful for assessing the water quality. Though RFG were valuable for inferring eutrophication, organic pollution, and mixing, but their dominance does not necessarily have a direct effect on the final Qr estimation.

Keywords Ecological indicators · Lotic systems · Reynolds functional groups · Qr index

\section{Introduction}

Surface waters are under an increasing ecological stress because of anthropogenic activities (UNEP 2002; FAO 2003; Srebotnjak et al. 2012). This is causing an extensive ecological degradation of the environment (Tejerina-Garro et al. 2005; Sabater 2008). A trend which will probably continue due to the increasing rates of water contamination, flow reduction, and overfishing 
(Malmqvist and Rund 2002; Rodrigues Capítulo et al. 2010). In this context, a growing demand for developing new methods for assessing the ecological status of freshwater ecosystems has incremented in the last 20 years, particularly in Europe through the Water Framework Directive (EC 2000), and in the USA through the Federal Water Pollution Control Act (U.S. 2008).

In riverine ecosystems, in comparison with lakes, the literature focusing on the characteristics of phytoplankton as a water quality indicator is far less developed (Stanković et al. 2012) than in lentic environments. Indeed, research related to water quality assessment, in the last 100 years, has been based on the study of the benthic elements of biota, mainly macroinvertebrates and diatoms (Stanković et al. 2012). Particularly in Argentina, the benthic communities as indicators of stream water quality have been intensively studied, mostly in the pampean region (e.g., Licursi and Gómez 2002; Rodrigues Capítulo et al. 2010; Cortelezzi et al. 2013; Licursi et al. 2016). However, phytoplankton may be also a "good" water quality estimator due to its central role in the aquatic food webs, its rapid response to environmental changes (Borics et al. 2014; Thackeray et al. 2013), and because the residence time of water in lowland streams may be enough for phytoplankton to develop substantial populations (Bolgovics et al. 2017).

Traditionally, phytoplankton monitoring has been based on species identification or in the estimation of biomass or chlorophyll- $a$ (e.g., Phillips et al. 2008; Mischke et al. 2011; Thackeray et al. 2013), accessory photosynthetic pigments, or different combinations of all of them (Friedrich and Pohlmann 2009). Nonetheless, phytoplankton biomass and human impacts are often difficult to associate properly. Compositional changes based on functional (Reynolds et al. 2002; Padisák et al. 2009), morphological (Kruk et al. 2010; Kruk and Segura 2012), and morpho-functional (Salmaso and Padisák 2007) classifications seem to better fulfill the need of understanding the relationships among pollutants and phytoplankton. Particularly in those environments where cultural eutrophication and organic matter are the main pollutants (Abonyi et al. 2012).

In lotic ecosystems, Borics et al. (2007) were the first to adapt a phytoplankton-based index (Q index of Padisák et al. (2006), developed for shallow lakes) and generate the phytoplankton assemblage index adapted for rivers (Qr index). Since then, other studies performed mainly in Europe have used this approach or other similar approaches to describe water quality of streams and rivers (e.g., Nõges et al. 2010; Piirsoo et al. 2008; Stanković et al. 2012; Reynolds et al. 2012; Abonyi et al. 2012, 2014; Borics et al. 2014; Wang et al. 2018). Particularly in Argentina, despite many studies describing phytoplankton structure and its relationships with human impacts (e.g. Loez and Salibián 1990; Del Giorgio et al. 1991; O'Farrell et al. 2002; Soares et al. 2007; Conforti et al. 2009), none of them have used phytoplankton assemblages as indicators of water quality.

Empirical and theoretical evidence shows that investments to improve water quality generate multiple economic, social, and environmental benefits (Srebotnjak et al. 2012). This is particularly true in areas where the water of rivers and streams is used for human consumption, crops irrigation, or has a recreational use. Hence, in the neotropical region, more studies are needed to test how well the phytoplankton functional approach reflects the water quality. The latter will be a useful input for the development of effective management strategies. In this study, we attempted to use the Qr index of Borics et al. (2007) to describe the water quality of a highly impacted tributary stream of the Middle Paraná River (Argentina). The Qr index was accompanied with an analysis of the phytoplankton functional traits to identify potential water quality threats, such as eutrophication and organic matter pollution. Finally, the Qr results obtained were explored to determine the main phytoplankton functional groups which may affect the Qr estimations.

\section{Material and methods}

\section{Study area}

The Tunas Stream (25 m above sea level) is localized in the pampean eco-region of Argentina, a vast area of $43,000,000$ hectares mainly characterized by agriculture and cattle raising activities (Wilson 2017). The Tunas Streams has, as main tributaries, the Saucecito and the Piedras Streams, and ends after $15 \mathrm{~km}$ in the Del Tala Stream which runs across a protected natural area (San Martín Park). This park is visited the whole year for educational activities and during the summer for recreational activities (mainly swimming). The Del Tala Stream finally ends in the Middle Paraná River, one of the most important rivers on the neotropical region 
(Iriondo et al. 2007) (Fig. 1a). For the study, three sampling station: station 1 (S1), station 2 (S2), and station 3 (S3) were selected according to their surrounding land use. Sampling stations were separated up to $4 \mathrm{~km}$ (between S1-S2 and S2-S3) on the stream course. S1 and S2 were linked to an agricultural area (Wilson 2017), while $S 2$ was also linked to industrial and urban uses. The General Manuel Belgrano Industrial Park (PIGMB), which encompass more than 20 industries, discharges treated wastewater (Pavé and Marchese 2005) in the Saucecito Stream, which in turn discharges its waters $1.75 \mathrm{~km}$ upstream of S2. Another tributary, the Piedras Stream, collects untreated municipal wastewater from San Benito City and pours its water above $1.60 \mathrm{~km}$ upstream from S2. Finally, the S3 sampling site, identified with no specific land use, was located downstream S2. S3 sampling station was selected to assess the selfdepuration capability of the stream in a sampling point situated before pouring its waters in the Del Talas Stream mentioned above (Fig. 1b).

\section{Samplings and analyses}

Environmental variables in water were measured monthly in the three sampling stations (S1, S2, and S3) from December 2014 until November 2015 considering three replicas on each sampling station $(n=$ 108 for each environmental variable) and being considered: temperature $\left({ }^{\circ} \mathrm{C}\right)$, dissolved oxygen (DO) (ppm), dissolved oxygen saturation (DO\% sat.), $\mathrm{pH}$, and conductivity $\left(\mathrm{mS} \mathrm{cm}^{-1}\right)$ using HANNA multiparametric proves, depth $\left(Z_{\mathrm{d}}\right)$ with an ultrasonic prove, and transparency with a Secchi disc $(m)$. The photic zone $\left(Z_{\text {eu }}\right)$ was estimated according to Koenings and Edmundson (1991) for turbid environments as $Z_{\text {eu }}=$ Secchi depth $(\mathrm{SD})(m) * 3.5$. The $Z_{\mathrm{d}}: Z_{\text {eu }}$ ratio was calculated as a measure of light availability in the water column. High values of this ratio indicate that the relative amount of time that phytoplankton spends in darkness increases (Reynolds 1994). Estimation of water flow $\left(\mathrm{m}^{3}\right.$ $\mathrm{s}^{-1}$ ) was performed following the criteria of UNESCO (2006) and precipitations data for the area ware obtained from Paraná Agricultural Experimental Station located at $7.67 \mathrm{~km}$. Sub-superficial samples for inorganic nutrients quantification in the water column were taken in $100 \mathrm{~mL}$ plastic bottles at the same time and at the same localization than further environmental variables $(n=108)$. Nitrate plus nitrite $\left(\mathrm{NO}_{3}{ }^{-}+\mathrm{NO}_{2}{ }^{-}\right)$was determined by reduction of nitrate with hydrazine sulfate and subsequent determination of nitrite by diazotization with sulfanilamide (Hilton and Rigg 1983), ammonium $\left(\mathrm{NH}_{4}{ }^{+}\right)$by the indophenol blue method, and soluble reactive phosphorus (SRP) by the ascorbic acid method (APHA 2005). Concentrations obtained were expressed in $\mu \mathrm{g} \mathrm{L}^{-1}$.

Phytoplankton samples of $150 \mathrm{~mL}$ were taken from the sub-surface area at the same time (from December 2014 until November 2015) and in the same locations (S1, S2, and S3) than the environmental variables $(n=108)$ and were immediately fixed with $1 \%$ acidified Lugol solution. Taxonomic classification was made according to Lee (2008) following keys and specific bibliography of each algal group, such as Krammer and Lange-Bertalot (1991), Zalocar de Domitrovic and Maidana (1997), Tell and Conforti (1986), Komárek and Fott (1983), Komárek and Anagnostidis (1998, 2005), and Komárek (2013), among other authors. Phytoplankton quantitative analyses were conducted following the Utermöhl (1958) method. Counting error was estimated according to Venrick (1978), accepting a maximum error of $20 \%$, and species counting was done at $\times 400$ of magnification. Phytoplankton biovolume $\left(\mathrm{mm}^{3} \mathrm{~L}^{-1}\right)$ was estimated following Hillebrand et al. (1999) criteria and functional classification of species was made according to Kruk et al. (2017) (see complementary material for more details). Dominance, evenness, and Shannon functional diversity were calculated considering the Reynolds functional groups (RFG) registered at each sampling station and sampling date.

The phytoplankton assemblage index adapted for rivers (Qr index) (Borics et al. 2007) was used as a water quality metric using all phytoplankton RFG registered during the study period. This metric reflects human impacts at different scales by using a specific indicator value $(F$, range from $1=$ bad to $5=$ excellent water quality) assigned to the different RFG. These indicator values were originally calculated by Borics et al. (2007) using the following components: (i) nutrient status (from oligotrophic to hypertrophic), (ii) turbulence (from standing waters to highly mix environment), (iii) enough time for the development of the given taxon (from pioneer to climax), and (iv) level of toxicity risk (from low to high) from each RFG. For those phytoplankton RFG absent in Borics (op. cit.), its $F$ values 


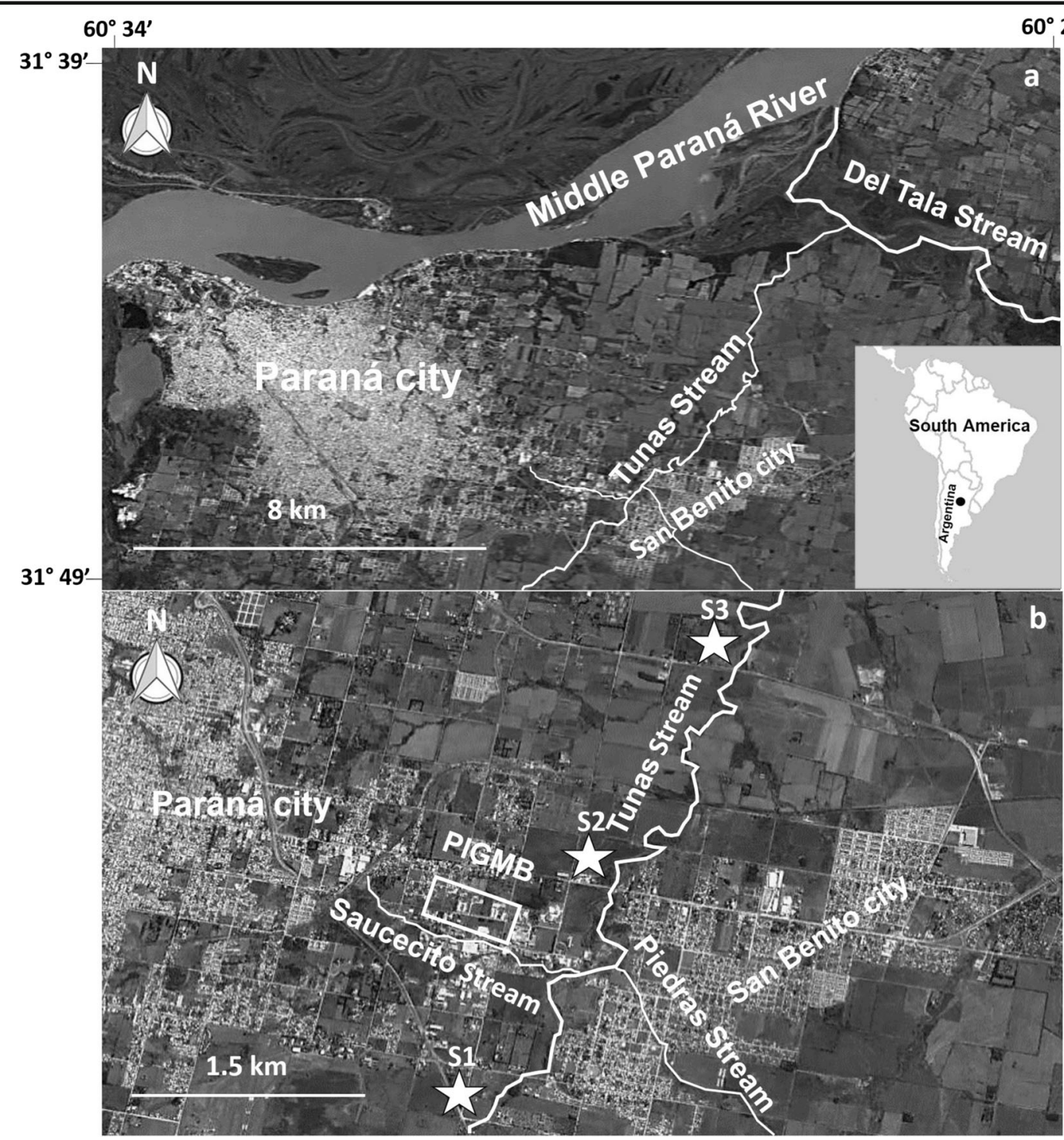

Fig. 1 Study area including Middle Paraná River, Tunas Stream tributaries (Saucecito and Piedras Streams) and Del Tala Stream (a). A more detailed image of the Tunas Stream where the sampling stations are indicated (b). PIGMB General Manuel Belgrano Industrial Park.

were here calculated following the same criteria (see complementary material). Finally, the Qr index was calculated for each sampling site and sampling date as follows:

$\mathbf{Q}=\sum \mathrm{p}_{\mathrm{i}} * \mathrm{~F}_{\mathrm{i}}$

where $p_{i}$ is the relative share of the $i$-functional group equal to $n_{i} / N$ being $n_{i}$ the biovolume of the $i$-group and $N$ the total phytoplankton biovolume. $F_{i}$ is the factor number assigned for each phytoplankton RFG in Borics et al. (2007) or in this study. Qr range from 0 to $5(0-1=$ "bad," 1-2 = "regular," 2-3 = "moderate," 3-4 = "good," 4-5 = "excellent" water quality). Results obtained for the Qr index in S1, S2, and S3 during the whole year of sampling were plotted by using the software Surfer v. 11.

Statistical analyses

Then, two-way ANOVAS were performed for the total phytoplankton biovolume and for each environmental variable comparing sampling stations (S1, S2, and S3) and seasons (summer, autumn, winter, and spring), by 
pooling data of sampling months and considering the principal effects. Previous transformation of the data to $\log _{10}(x+1)$ to secure a normal distribution of data and subsequent verification of the homogeneity of the variances with the Levene test were used (Zar 1996). Tukey tests were used for pairwise post hoc comparisons on sampling stations. The statistical independence among phytoplankton biovolume of the three sampling stations (S1, S2, and S3) was tested by using the autocorrelation test of Durbin-Watson (Farebrother 1980). Principal coordinates analyses (PCO) were performed for each season (summer, autumn, winter, and spring) by pooling data of sampling months and using the Bray-Curtis distance measure. This analysis was used for characterizing the three sampling stations (S1, $\mathrm{S} 2$, and S3) through the examination of the RFG preference (water mix conditions, trophic level, and organic matter presence) based on Reynolds et al. (2002) and Padisák et al. (2009). PCO analyses were accompanied by permutational multivariate analyses of variance (PERMANOVAS) to verify PCO statistical significance $(p<0.05)$.

Multiple regression models (GLM) with Gaussian adjustment were run for the assessment of the RFG which mainly influenced the Qr index values (water quality) obtained for each sample. The Qr relations were tested with several diversity estimators (dominance, evenness, and Shannon phytoplankton functional diversity). Co-linear explanatory variables were automatically omitted from analyses. In both regression categories, several models $(k)$ were run until the optimum model was found, using the Akaike criteria (AIC), the percentage explanation of total variation, and the minimum number of significative $(p<0.05)$ explanatory variables. All the statistical analyses were performed using the software CANOCO for Windows v. 5.10 (ter Braak and Šmilauer 2012) and PAST v. 3.13 (Hammer et al. 2018).

\section{Results}

Physical and chemical variables

Changes among sampling stations (S1, S2, and S3) and seasons (summer, autumn, winter, and spring) were observed across the studied period. Regarding seasons, temperature was highest during summer and autumn while $\mathrm{pH}$ was highest during winter and spring. DO and DO\% showed the highest values during winter. Conductivity values increased during autumn and winter; nutrients ( $\mathrm{SRP}, \mathrm{NO}_{2}{ }^{-}-\mathrm{NO}_{3}{ }^{-}$, and $\mathrm{NH}_{4}{ }^{+}$) reached the highest concentration during the summer and the lowest values during the winter (except for $\mathrm{NH}_{4}{ }^{+}$). The $Z_{\mathrm{d}}: Z_{\mathrm{eu}}$ ratio ( $>1$ indicates high mix) showed high values during the summer and low values during all other seasons.

Regarding sampling stations, in summer a decrease in SRP concentration was registered in S3 while nitrogen forms $\left(\mathrm{NO}_{2}{ }^{-}-\mathrm{NO}_{3}{ }^{-}\right.$and $\left.\mathrm{NH}_{4}{ }^{+}\right)$increased. The opposite was observed for $\mathrm{S} 1-\mathrm{S} 2$ where higher SRP and lower nitrogen concentrations $\left(\mathrm{NO}_{2}{ }^{-}-\mathrm{NO}_{3}{ }^{-}\right.$and $\left.\mathrm{NH}_{4}{ }^{+}\right)$ were found. The other environmental parameters showed similar values among sampling stations, except for water flow which was higher in S2, and oxygen concentration which was lower in S2-S3 compared with S1. During autumn, once again a decrease in DO and DO\% saturation was found in S2 and S3, in comparison with S1. Conversely, SRP showed lower concentrations in S2-S3 than in S1. S2 also showed the highest water flow values. In winter, higher SRP concentrations were detected in S1 compared with S2-S3 while the highest $\mathrm{NH}_{4}{ }^{+}$concentrations were observed in S3. Finally, during spring, a drop of DO and DO\% in $\mathrm{S} 2$ and $\mathrm{S} 3$ was found. $\mathrm{NO}_{2}{ }^{-}-\mathrm{NO}_{3}{ }^{-}$and SRP showed high concentrations in all sampling stations, though $\mathrm{NH}_{4}{ }^{+}$was higher in $\mathrm{S} 3$. The $Z_{\mathrm{d}}: Z_{\mathrm{eu}}$ ratio reflected similar conditions for the three sampling stations in all seasons, except during the spring when the ratio was low in S1-S2 and high in S3 (Table 1).

The two-way ANOVAS comparisons showed statistically significant differences among seasons for all the environmental variables tested (temperature $F=61.89$, $p<0.001$; $\mathrm{pH} F=18.34, p<0.001$; conductivity $F=$ $117.07, p<0.001$; DO $F=31.52, p<0.001$; DO\% sat. $F$ $=22.73, p<0.001 ; Z_{\mathrm{d}}: Z_{\text {eu }}$ ratio $F=20.43, p<0.001$; water flow $F=35.54, p<0.001$; precipitations $F=$ $19.71, p<0.001$; SRP $F=35.35, p<0.001 ; \mathrm{NO}_{2}{ }^{-}$ $\mathrm{NO}_{3}{ }^{-} F=34.18, p<0.001$; and $\mathrm{NH}_{4}{ }^{+} F=19.82, p<$ $0.001)$. Differences were found among sampling stations (S1, S2, and S3) for DO and DO\% ( $F=11.56, p$ $<0.001$ and $F=8.60, p<0.001$, respectively) between $\mathrm{S} 1-\mathrm{S} 2$ and S1-S3 (S1 > S2 and S3). Differences were also detected for the water flow $(F=69.42, p<0.001)$ between $\mathrm{S} 2-\mathrm{S} 1$ and $\mathrm{S} 2-\mathrm{S} 3(\mathrm{~S} 2>\mathrm{S} 1$ and $\mathrm{S} 3), Z_{\mathrm{d}}: Z_{\mathrm{eu}}$ ratio $(F=8.49, p<0.001)$ between $\mathrm{S} 3-\mathrm{S} 1$ and $\mathrm{S} 3-\mathrm{S} 2$ $(\mathrm{S} 3>\mathrm{S} 1$ and S2), $\mathrm{SRP}(F=11.23, p<0.001)$ between $\mathrm{S} 1-\mathrm{S} 2$ and $\mathrm{S} 1-\mathrm{S} 3$ (S1 $>\mathrm{S} 2$ and $\mathrm{S} 3)$, and $\mathrm{NH}_{4}{ }^{+}(F=$ $9.98, p<0.001)$ between S3-S1 and S3-S2 $(\mathrm{S} 3>\mathrm{S} 1$ 


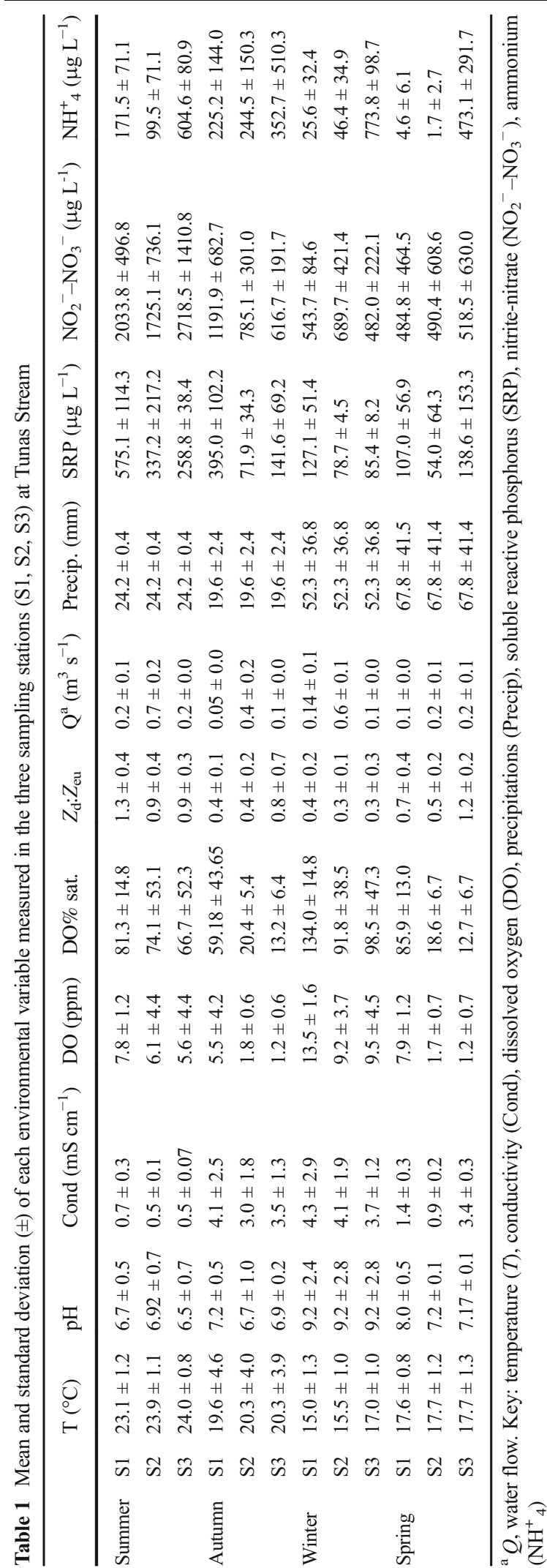

and S2). A lack of significance was found for temperature, $\mathrm{pH}$, conductivity, precipitations, and $\mathrm{NO}_{2}{ }^{-}-\mathrm{NO}_{3}{ }^{-}$ concentrations when sampling stations were compared $(p>0.05$ for all of them).

\section{Phytoplankton functional groups}

A total of 156 phytoplankton taxa were recorded: these corresponded to $21 \mathrm{RFG}$. The autocorrelation test of Durbin-Watson showed absence of correlation of total phytoplankton biovolume among sampling stations ( $\mathrm{S} 1$, $\mathrm{S} 2$, and $\mathrm{S} 3)$ during the studied period $(U=1.6, p=0.1)$. Total phytoplankton biovolume showed maximum values (> $40 \mathrm{~mm}^{3} \mathrm{~L}^{-1}$ ) during June, September, and November, in S3 (Fig. 2g, j, 1). The minimum values $\left(<10 \mathrm{~mm}^{3} \mathrm{~L}^{-1}\right)$ were registered in $\mathrm{S} 1$ and $\mathrm{S} 2$ particularly during summer (December, January, February) (Fig. 2a, b, c) and autumn (April and May) (Fig. 2e, f). The two-way ANOVA showed differences among seasons $(F=25.53, p<0.001)$ and among sampling stations $(F=29.30, p<0.001)$. The Tukey test indicated statistically significant differences for $\mathrm{S} 1$ versus $\mathrm{S} 3$ and $\mathrm{S} 2$ versus $\mathrm{S} 3$ ( $p<0.001$ for both, $\mathrm{S} 3>\mathrm{S} 1$ and $\mathrm{S} 2)$.

The PCO analyses explained more than $40 \%$ of total variation in all seasons: summer (62\%), autumn (45\%), winter (45\%), and spring (64\%). Sampling stations S1 and S2 had largely similar RFG arrangements, which differed from S3. During the summer, S1 and S2 were characterized by RFG indicators of mid-mixed waters and eutrophic conditions. S3 showed to be related to mixed, eutrophic, organic matter enriched waters (Fig. 3a, Table 2). The mentioned differences between sampling sites were statistically significant (PERMANOVA, $F=7.69, p=0.0001)$. During Autumn, once again $\mathrm{S} 1+$ S2 showed eutrophic, standing water conditions while S3 indicated eutrophic organic enriched conditions, with however a dissimilar arrangement of RFG (Fig. 3b, Table 2) (PERMANOVA, $F=4.62, p=0.0001$ ). During the winter $\mathrm{S} 1+\mathrm{S} 2$ were related to eutrophic, mid-mix waters, while in S3 RFG arrangement indicated eutrophic, mid-mix, organic enriched, low nitrogen content conditions (Fig. 3c, Table 2) (PERMANOVA, $F=6.58$, $p=0.0001$ ). Finally, the spring season indicated that $\mathrm{S} 1$ and S2 were characterized by RFG indicators of standing, eutrophic waters, whereas S3 was linked with organic enriched, eutrophic, low nitrogen content, and mid-mix conditions (Fig. 3d, Table 2) (PERMANOVA, $F=19.04, p=0.0001)$. 

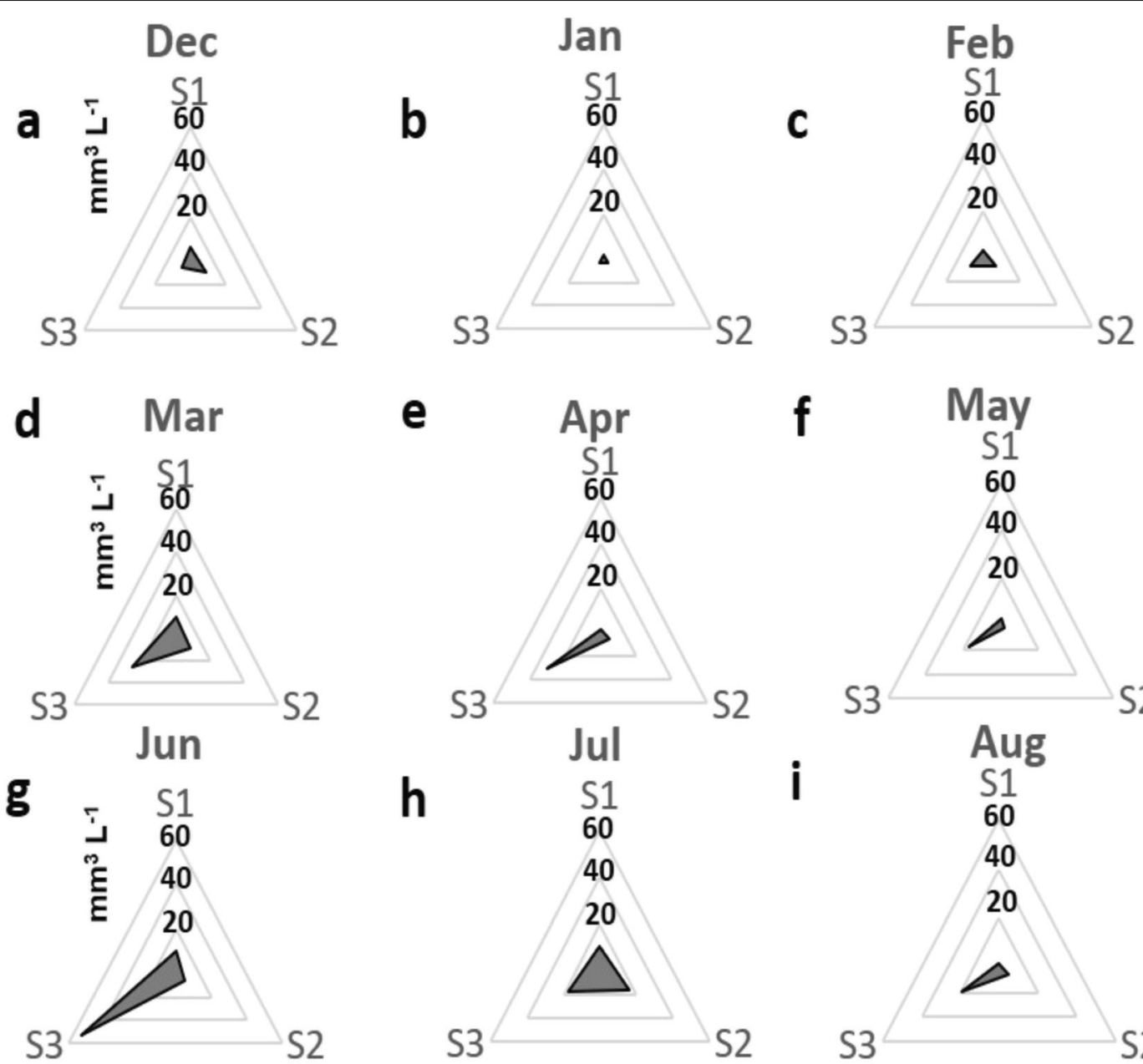

h
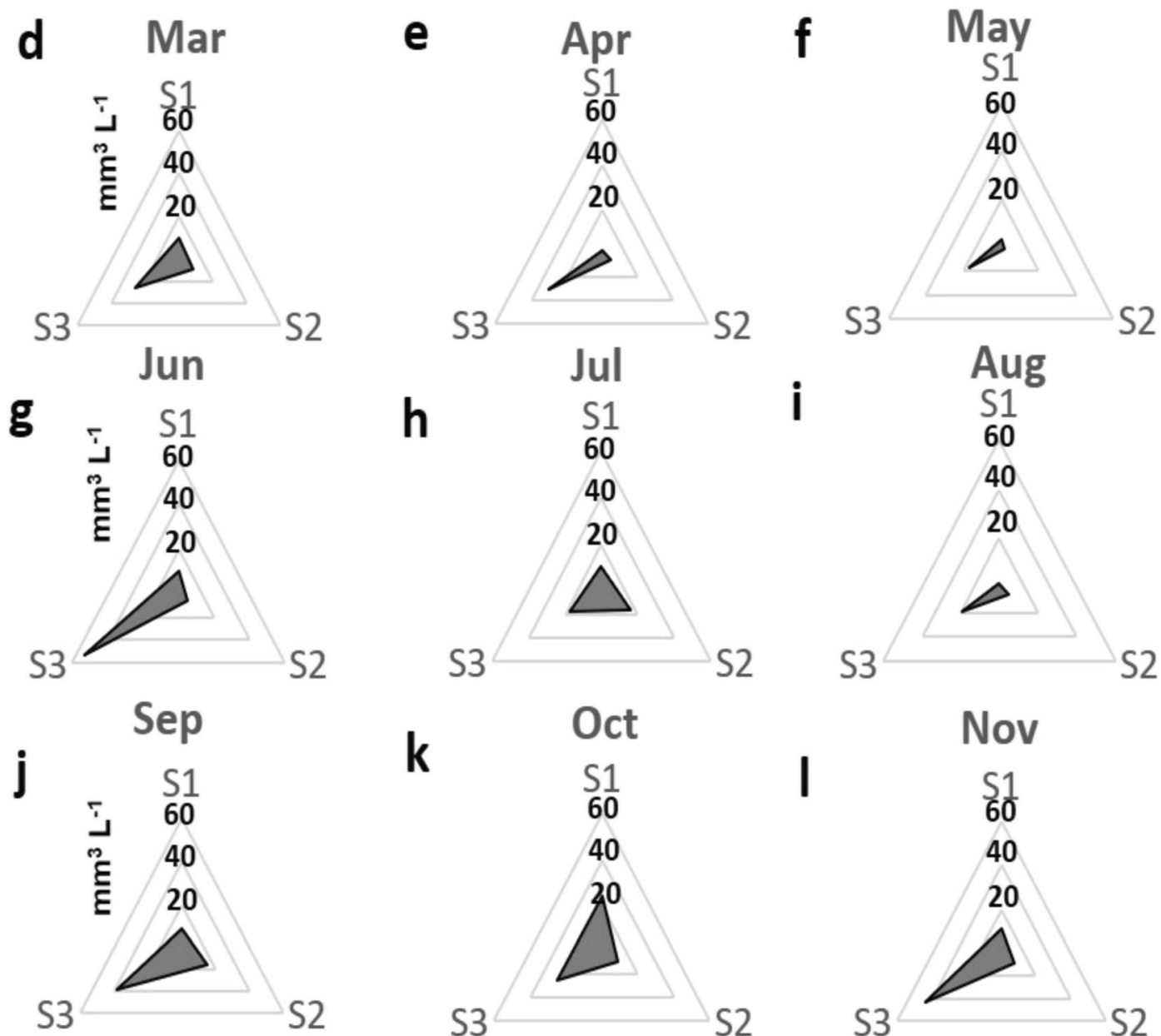

Nov
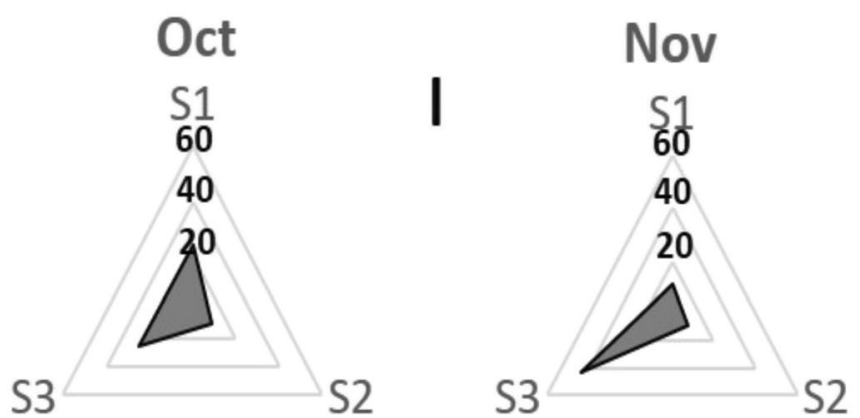

Fig. 2 Total phytoplankton biovolume $\left(\mathrm{mm}^{3} \mathrm{~L}^{-1}\right)$ registered for each sampling station (S1, S2, and S3) (mean values) and sampling month (from December 2014 to November 2015).

Water quality and forcing factors

The Qr index showed intermediate values ("moderate" water quality) for most part of the year in S1, with improvements in water quality ("good") during January (summer season), being $\mathbf{K}$ and $\mathbf{Y}$ the dominant RFG (maximum biovolume). "Moderate" water quality was also indicated for S2, except during February-March and October-November when "regular" conditions were indicated. $\mathbf{W}_{\mathbf{1}}, \mathbf{Y}, \mathbf{M P}, \mathbf{G}$, $\mathbf{M}$, and $\mathbf{K}$ were the RFG best represented in terms of biovolume in S2. S3 showed most part of the year "regular" conditions, except during December and winter months (June, July, and August). The RFG F, 

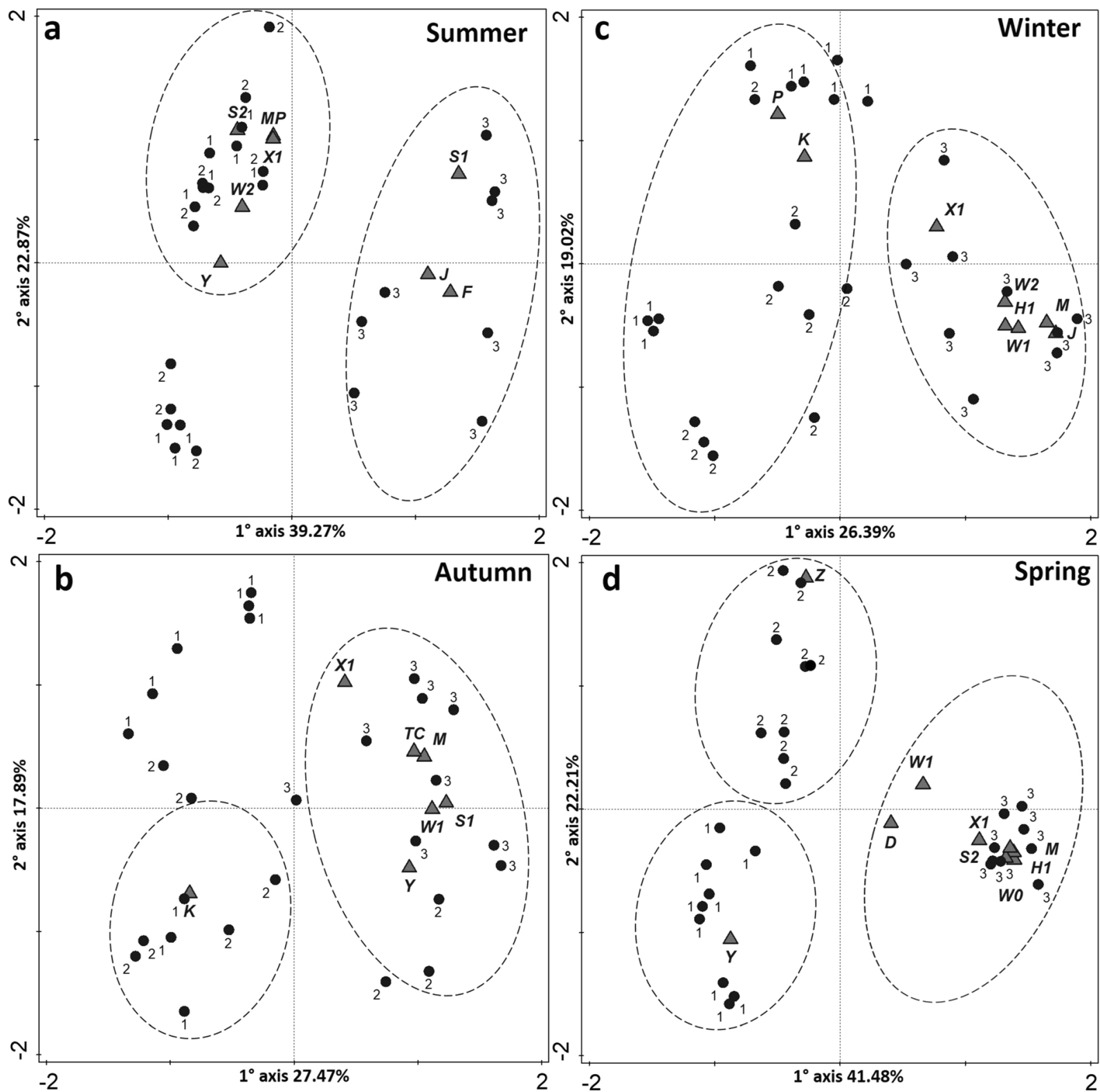

Fig. 3 Principal coordinates analyses (PCO) performed for each season: summer (a), autumn (b), winter (c), and spring (d), being indicated sampling stations (S1, S2, and S3) and the Reynolds

Functional Groups (RFG). Only those RFG which had a correlation with the ordination axes (1 and 2) \pm 0.5 are displayed

$\mathbf{W}_{\mathbf{0}}, \mathbf{W}_{\mathbf{1}}$, and $\mathbf{W}_{\mathbf{2}}$ were the dominant groups in $\mathrm{S} 3$ (Fig. 4).

The GLM analysis explained $54 \%$ of total variation $(F=23.63, p<0.0001)$. The RFG MP and $\mathbf{X}_{\mathbf{1}}$ were positively correlated to an improvement in water quality (high Qr values), while $\mathbf{M}, \mathbf{S}_{\mathbf{1}}$, and $\mathbf{Z}$ were negatively correlated (Table 3 ). Diversity phytoplankton indicators (dominance, evenness, or Shannon phytoplankton functional diversity)

showed absence of correlation with the Qr index (GLM, $p>0.05$ ).

\section{Discussion}

Results showed "moderate" water quality for most part of the year in S1 (with an improvement to "good" during January), and "moderate" water quality in autumn- 
Table 2 Reynolds functional groups (RFG) habitat characteristics based on Reynolds et al. (2002) and Padisák et al. (2009) and some representative taxa registered in Las Tunas Stream. It is also indicated their $F_{i}$ value (range from 0 (bad) to 5 (excellent)) based on Borics et al. (2007)

\begin{tabular}{|c|c|c|c|}
\hline RFG & Habitat & Some representative taxa in this study & $F_{i}$ \\
\hline B & Vertically mixed, mesotrophic & Cyclotella meneghiniana Kützing; Entomoneis alata (Ehrenberg) Ehrenberg & 4 \\
\hline D & Shallow, nutrient enriched, turbid & Nitzschia acicularis (Kützing) W.Smith; Synedra acus Kützing & 4 \\
\hline $\mathbf{F}$ & Mixed, meso-eutrophic waters & Ankistrodesmus gracilis (Reinsch) Korshikov; Oocystis elliptica West & 3 \\
\hline G & Stagnant, nutrient enriched & Eudorina elegans Ehrenberg; Pandorina morum (O.F. Müller) Bory & 1 \\
\hline $\mathbf{H}_{1}$ & Nostocales, nitrogen-fixers & Dolichospermum sp. & 1 \\
\hline $\mathbf{J}$ & shallow, mixed, organic enriched & Actinastrum hantzschii Lagerheim; Crucigenia crucifera (Wolle) O. Kuntze & 2 \\
\hline $\mathbf{K}$ & Shallow, standing, nutrient enriched & Aphanocapsa delicatissima West \& West & 2 \\
\hline $\mathbf{L}_{\mathbf{O}}$ & Deep or shallow, oligo to eutrophic & Coelomoron pusillum (Van Goor) Komárek & 1 \\
\hline M & Standing, eutrophic waters & Microcystis aeruginosa (Kützing) Kützing & 0 \\
\hline MPa & Mixed waters, inorganically turbid & Cocconeis placentula Ehrenberg; Eunotia minor (Kützing) Grunow & 4 \\
\hline $\mathbf{N}$ & Mixed, mesotrophic waters & Closteriopsis longissima (Lemmermann) Lemmermann & 3 \\
\hline $\mathrm{Pa}$ & Mixed, eutrophic waters & Aulacoseira distans (Ehrenberg) Simonsen; Melosira lineata (Dillwyn) C.Agardh & 3 \\
\hline $\mathbf{S}_{1}$ & Mixed, eutrophic, turbid waters & Limnothirix sp. & 0 \\
\hline $\mathbf{S}_{\mathbf{2}}$ & Mixed waters, inorganically turbid & Glaucospira laxissima West & 0 \\
\hline $\mathbf{T}_{\mathbf{C}}$ & Standing, eutrophic waters & Lyngbya sp. & 2 \\
\hline $\mathbf{W}_{\mathbf{0}}$ & Standing or mix, high organic content & Chlamydomonas metastigma Stein; Chlamydomonas pasiva Ehrenberg & 1 \\
\hline $\mathbf{W}_{1}$ & Standing, high organic content & Euglena acus (O.F.Müller) Ehrenberg; Lepocinclis fusiformis (Carter) Lemmermann & 1 \\
\hline $\mathbf{W}_{2}$ & Mixed, meso-eutrophic & Strombomonas acuminata (Schmarda) Deflandre; Strombomonas caudata Skuja & 3 \\
\hline $\mathbf{X}_{1}$ & Shallow, nutrient enriched & Chlorella vulgaris Beyerinck [Beijerinck]; Scenedesmus ecornis (Ehrenberg) Chodat & 3 \\
\hline $\mathbf{Y}$ & Standing, nutrient enriched conditions & Cryptomonas curvata Ehrenberg; Cryptomonas ovata Ehrenberg & 3 \\
\hline $\mathrm{Za}$ & Standing, mesotrophic conditions & Synechococcus sigmoideus (G.T.Moore \& N.Carter) Komárek & 1 \\
\hline
\end{tabular}

${ }^{\mathrm{a}}$ The $F_{i}$ value was assigned in this study based on the criteria exposed in Borics et al. (2007). Consult complementary material for more details

winter for S2. S3 was the most affected section, with "regular" water quality most part of the year (except during winter). The RFG arrangements suggested eutrophic conditions in S1 and S2. In these two sections, we found the highest SRP concentrations. This area is composed by vertisol kind soils, which have naturally low content of available phosphorus (de Petre and Stephan 1998; Battista 2004). As explained by Allan (2004), diffuse nutrient contamination from fertilizers run-off in areas intensely used for agriculture (Wilson 2017) would be the most expected cause of eutrophication in $\mathrm{S} 1$ and $\mathrm{S} 2$ sections.

S3 was characterized by organic pollution the whole year, with the lowest DO\% saturations and the highest $\mathrm{NH}_{4}{ }^{+}$concentrations. Indeed, the Piedras Stream (located upstream of S2 sampling point) flows through the San Benito city, a highly populated area (9489 inhabitants) which has a lack of municipal sewage water treatment. It is possible that organic matter discharged near S2 would be then transported downstream to S3. This may be the case during the summer and the autumn. Indeed, in these two seasons, the lowest DO\% were recorded in both sections (S2 and S3), the highest water flow was registered in $\mathrm{S} 2$, and the highest $\mathrm{NH}_{4}{ }^{+}$ concentrations in $\mathrm{S} 3$.

Moreover, during the winter and the spring, the RFG $\mathbf{H}_{\mathbf{1}}$ (Dolichospermum species in this study), which suggests low nitrogen concentration (Padisák et al. 2009), were found in S3. Species in this group actively fix atmospheric nitrogen when they have high heterocyte density (de Tezanos Pinto and Litchman 2010; Frau et al. 2018a), though we observed lack of heterocytes and hence fixation. These results suggest that the high ammonium concentration recorded in S3 favored the proliferation of this cyanobacteria group without fixing nitrogen.

The results obtained reflected the main land uses, showing that the Tunas stream has a low auto- 


\begin{tabular}{|r|c|c|c|c|c|c|c|c|c|c|c|c|}
\hline & Dec & Jan & Feb & Mar & Apr & May & Jun & Jul & Aug & Sep & Oct & Nov \\
\hline S3 & $F$ & F & F & W1 & (X1) & W1 & W1 & W2 & W0 & W0 & W0 & W0 \\
\hline S2 & W1 & Y & (MP) & Y & (MP) & W2 & X1 & G & F & K & W1 & W1 \\
\hline S1 & (MP) & Y & X1 & X1 & (MP) & X2 & X1) & K & K & K & Y & Y \\
\hline
\end{tabular}

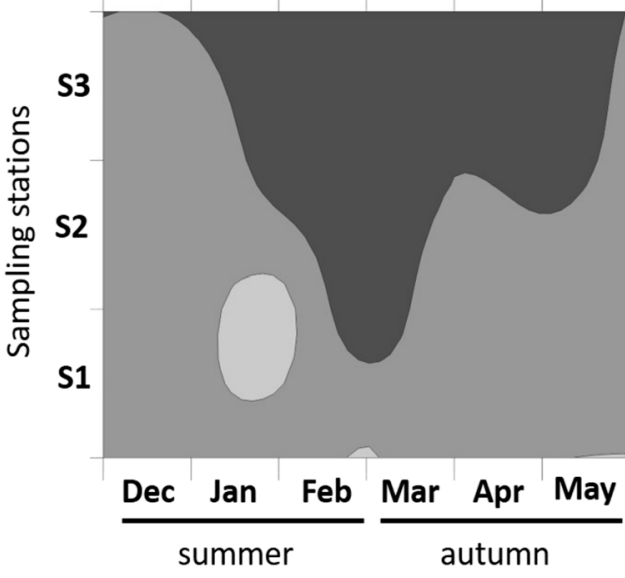

Fig. 4 Monthly and longitudinal (sampling stations S1, S2, and S3) differences of the Qr index in the Tunas Stream during the study period. The table shows the dominant Reynolds Functional Group (maximum biovolume) registered for each month and

depuration capability; due to S3 having, without any specific land used identified, the worst water quality rating throughout the year. Moreover, the RFG arrangement analysis was useful as a complement of the Qr index, giving a plus for the interpretation of the ecological conditions of this stream. This approach has been frequently used in the past to detect eutrophication or organic pollution conditions in lakes and rivers in other latitudes (e.g., Piirsoo et al. 2010; Stanković et al. 2012; Reynolds et al. 2012; Wang et al. 2018); being this study the first in considering this approach in this area. Results obtained suggests that in S2, a sanitation strategy should

Table 3 Multiple regression model (GLM) statistics using Qr values as response variable and Reynolds Functional Groups (RFG) as predictors (number of models run, $k=5, n=108$ )

\begin{tabular}{lllll}
\hline Term & $b$ & $\mathrm{SE}$ & $T$ & $p(T)$ \\
\hline (Intercept) & 2.467 & 0.10 & 24.67 & $<0.001$ \\
$\mathrm{M}$ & -0.06 & 0.01 & -6.35 & $<0.001$ \\
$\mathrm{MP}$ & 0.02 & 0.01 & 2.85 & 0.01 \\
$\mathrm{~S}_{1}$ & -0.03 & 0.01 & -5.44 & $<0.001$ \\
$\mathrm{X}_{1}$ & $9.07 \mathrm{E}^{-08}$ & $2.27 \mathrm{E}^{-08}$ & 4 & $1.2 \mathrm{E}^{-04}$ \\
$\mathrm{Z}$ & $-3.30 \mathrm{E}^{-07}$ & $1.30 \mathrm{E}^{-07}$ & -2.53 & 0.01 \\
\hline
\end{tabular}

be applied to reduce the organic matter charge, which will result in a beneficial effect on S3. This in turn will exert a beneficial effect on the Del Tala Stream which receives the water from the Tunas Stream and which runs across a natural protected area with recreational value. The problem of eutrophication, however, may be a more difficult task; diffuse nutrients run-off from agriculture lands are a problem more difficult to manage. Results also showed that the RFG classification failed to infer the presence of other sources of pollution, like herbicides or metals linked to fertilizers, very frequent in lowland polluted rivers linked to agricultural uses (Arias et al. 2007). In this respect, new studies focused on the indicator value of RFG classification of other kind of pollutants are needed.

Regarding the Qr index performance, Abonyi et al. (2012) already pointed out that this index is unable to distinct natural versus cultural eutrophication and is unable to penalize the presence of invasive or brackish phytoplankton species. In the study area, the problem of distinguishing natural from human eutrophication is, certainly, an unresolved issue shared by many other indexes used for water quality estimation. It is due to the multiple interacting environmental factors, food web compartments, and the naturally high spatial-temporal 
variability of lotic ecosystems (see Bennett et al. 2017). In the pampean region of Argentina, we have only one register of an invasive species (the dinoflagellate Ceratium furcoides (Levander) Langhans) (Meichtry de Zaburlín et al. 2016). This species is classified as $\mathbf{L}_{\mathbf{O}}$ in the RFG classification and is an indicator of bad water quality in the Qr index. Finally, lowland pampean streams have high conductivity (Rodrigues Capítulo et al. 2010) which determine that high salinity adapted species are frequent. Nonetheless, one disadvantage of index, already pointed out in Frau et al. (2018a), is that the Qr index and other similar indexes have some requirements. Certainly, the $\mathrm{Qr}$ index application require expert knowledge of RFG, a high training on phytoplankton taxonomy to reach at least the genus level, and environmental information, not always accessible, to make the RFG classification.

Three RFG which were absent in the original publication of Borics et al. (2007) were included in this study (see complementary material for the full description of the groups). These groups were: $\mathbf{M P}, \mathbf{P}$, and $\mathbf{Z}$. We assigned to MP (mainly Gyrosigma and Gomphonema species in this study) an $F$ value in the Qr index of 4 (high-quality indication), considering that these species are frequently linked to mesotrophic conditions (Prygiel and Coste 2000), mixed waters, and have a low-toxicity risk. For $\mathbf{P}$ and $\mathbf{Z}$ groups, we assigned them an indicator value $(F)$ of 3 (moderate quality indication) and 1 (bad quality indication), respectively. The first is related to eutrophic mixed water conditions (Reynolds 2006; Padisák et al. 2009) and at least Aulacoseira and Melosira (both included in $\mathbf{P}$ in this study) have a lowtoxicity risk. Synechoccocus and Synechocystis ( $\mathbf{Z}$ group) have been classified as representative from oligotrophic waters (Reynolds 2006; Padisák et al. 2009). Nonetheless, we assigned to this group an $F$ value of 1 . We found them in eutrophic, standing conditions during the spring in S2, and this group is related with the production of some unlethal toxins (Jakubowska and Szelagg-Wasielewska 2015). In Kruk et al. (2017), Synechoccocus and Synechocystis were suggested to be moved to $\mathbf{L}_{\mathbf{O}}$, which in Borics et al. (2007) has an indicator value of $F=1$. Being this consistent with the value assigned here.

The GLM analysis showed that $\mathbf{M}, \mathbf{S}_{\mathbf{1}}$, and $\mathbf{Z}$ ( $F$ value in the Qr index ranging from 0 to 2 ) were linked to a drop in water quality while $\mathbf{X}_{\mathbf{1}}$ and MP ( $F$ values of 3 and 4 , respectively) to an improvement in water quality. However, based on our results, we conclude that this dominance — of good or bad quality indicators - might not be representative of the final water quality estimation obtained. For example, during April, $\mathbf{X}_{\mathbf{1}}$ and $\mathbf{M P}$ positively linked to high Qr values in the GLM and indicators of good water quality-were dominant in the three sampling stations (S1, S2, and S3). However, a "regular" water quality was informed in S3. This is because water quality estimation in the Qr index depends on the sum of all RFG present in the sample and their relative biovolume, so dominance of one RFG not necessary reflect the final water quality estimation given by the Qr index.

\section{Conclusions}

This study represents an early field in water quality assessment using phytoplankton in lowland streams of the neotropical region. Results obtained in the Tunas Stream showed that the Qr index accompanied with a phytoplankton functional trait characterization were valuable tools to describe different segments of the stream and to identify the most impacted sections. All sampling stations were nutrient enriched. S3 was the most impacted section, as it suffered both eutrophication and organic matter pollution. Showing the index final calculations lack of influence of the dominant RFG in samples. We conclude that the Qr index could be a valuable indicator of water quality in this lowland stream. The information gathered can be used to inform managers about the water quality and the main pollutants in the stream, performed at a low cost and with a high level of confidence.

Acknowledgments We thank C. De Bonis for his assistance in the field and Dr. P. de Tezanos Pinto for the language assistance.

Funding information This study was partially supported by the project PICT 1017/2014.

\section{References}

Abonyi, A., Leitão, M., Lancon, A. N., \& Padisák, J. (2012). Phytoplankton functional groups as indicators of human impacts along the River Loire (France). Hydrobiologia, 698, 233-249.

Abonyi, A., Leitão, M., Stanković, I., Borics, G., Várbíróc, G., \& Padisák, J. (2014). A large river (River Loire, France) survey to compare phytoplankton functional approaches: do they 
display river zones in similar ways? Ecological Indicators, $46,11-22$.

Allan, J. D. (2004). Landscapes and riverscape: the influence of land use on stream ecosystems. Annual Review of Ecology, Evolution, and Systematics, 35, 257-284.

APHA. (2005). Standard methods for the examination of water and wastewater (21st ed.). USA: American Public Health Association.

Arias, A. R., Forsin Buss, D., Ferreira, I. A., Moreira Freire, M., Egler, M., Mugnai, R., \& Fernades, B. D. (2007). Use of bioindicators for assessing and monitoring pesticides contamination in streams and rivers. Ciência \& Saúde Coletiva, $12,61-72$.

Battista, J. J. (2004). Manejo de Vertisoles en Entre Ríos. Revista Científica Agropecuaria, 8, 37-43.

Bennett, M. G., Schofield, K. A., Lee, S. S., \& Norton, S. B. (2017). Response of chlorophyll a to total nitrogen and total phosphorus concentrations in lotic ecosystems: a systematic review protocol. Environmental Evidence, 6, 1-13.

Bolgovics, A., Várbíró, G., Ács, E., Trábert, Z., Kiss, K. T., Pozderka, V., \& Borics, G. (2017). Phytoplankton of rhithral rivers: its origin, diversity and possible use for quality-assessment. Ecological Indicators, 81, 587-596.

Borics, G., Várbíró, G., Grigorszky, I., Krasznai, E., Szabó, S., \& Kiss, K. T. (2007). A new evaluation technique of potamoplankton for the assessment of the ecological status of rivers. Large Rivers, 17. Archiv für Hydrobiologie Supplement, 161, 465-486.

Borics, G., Görgényi, J., Grigorszky, I., László-Nagy, Z., Tóthmérész, B., Krasznai, E., \& Várbíró, G. (2014). The role of phytoplankton diversity metrics in shallow lake and river quality assessment. Ecological indicators, 45, 28-36.

Conforti, V., Ohirko, E., \& Gómez, N. (2009). Euglenophyta from a stream of pampean plain subjected to anthropic effects: $\mathrm{A}^{\circ}$ Rodriguez. Algological studies, 131, 63-86.

Conzonno, V. H. (2009). Limnología Química. Argentina: Universidad Nacional de La Plata.

Cortelezzi, A., Sierra, M. V., Gómez, N., Marinelli, C., \& Rodrigues Capítulo, A. (2013). Macrophytes, epipelic biofilm, and invertebrates as biotic indicators of physical habitat degradation of lowland streams (Argentina). Environmental Monitoring Assessment, 185, 5801-5815.

de Petre, A. \& Stephan, S. (1998). Características pedológicas y agronómicas de los Vertisoles de Entre Ríos, Argentina. Facultad de Ciencias Agropecuarias, Universidad Nacional de Entre Ríos.

de Tezanos Pinto, P., \& Litchman, E. B. (2010). Eco-physiological responses of nitrogen-fixing cyanobacteria to light. Hydrobiologia, 639, 63-68.

del Giorgio, P., Vinocur, A., Lombardo, R. J., \& Tell, G. (1991). Progressive changes in the structure and dynamics of the phytoplankton community along a pollution gradient: a multivariate approach. Hydrobiologia, 224, 129-154.

Farebrother, R. W. (1980). Pan's procedure for the tail probabilities of the Durbin-Watson statistic. Applied Statistics, 29, 224227.

Food and Agriculture Organization (FAO). (2003). Review of world water resources by country. Italy: FAO.

Frau, D., de Tezanos Pinto, P. \& Mayora, G. (2018a). Are cyanobacteria total, specific and trait abundance regulated by the same environmental variables? Annales de
Limnologie - International Journal of Limnology 54. https://doi.org/10.1051/limn/2017030.

Frau, D., Mayora, G., \& Devercelli, M. (2018b). Phytoplankton based water quality metrics: feasibility of its application in a neotropical shallow lake. Marine and Freshwater Research, 69, 1746-1754.

Friedrich, G., \& Pohlmann, M. (2009). Long term plankton studies at the lower Rhine/Germany. Limnologica, 39, 14-39.

Hammer, Ø., Harper, D. A., \& Ryan, P. D. (2018). PASTpalaeontological statistics, version 3.18. Norway: University of Oslo.

Hillebrand, H., Dürselen, C., Kirschtel, D., Pollingher, U., \& Zohary, T. (1999). Biovolume calculation for pelagic and benthic microalgae. Journal of Phycology, 35, 403-424.

Hilton, J., \& Rigg, E. (1983). Determination of nitrate in lake water by the adaptation of the hydrazine-copper reduction method for use on a discrete analyzer: performance statistics and an instrument-induced difference from segmented flow conditions. Analyst, 108, 1026-1028.

Iriondo, M. H., Paggi, J. C., \& Parma, M. J. (2007). The Middle Paraná River. Limnology of a Subtropical Wetland. Berlin: Springer.

Jakubowska, N., \& Szelag-Wasielewska, E. (2015). Toxic picoplanktonic cyanobacteria-review. Marine Drugs, 13, 1497-1518.

Koenings, J. P., \& Edmundson, J. A. (1991). Secchi disk and photometer estimates of light regimes in Alaskan lakes: effects of yellow color and turbidity. Limnology and Oceanography, 36, 91-105.

Komárek, J. (2013). Cyanoprokaryota.Teil/3rd part: heterocytous genera. In G. L. Büdel, M. Krienitz, \& M. Chagerl (Eds.), Süswasserflora von Mitteleuropa (Freshwater flora of Central Europe). Heidelberg: Springer Spektrum.

Komárek, J., \& Anagnostidis, K. (1998). Cyanoprokaryota. Teil 1: Chroococcales. In H. Ettl, G. Gärtner, H. Heynig, \& D. Mollenhauer (Eds.), Süsswasserflora von Mitteleuropa 19/ 1. Gustav Fisher Verlag: Jena.

Komárek, J., \& Anagnostidis, K. (2005). Cyanoprokaryota. Teil 2: Oscillatoriales. In B. Büdel, G. Gärtner, L. Krienitz, \& M. Schagerl (Eds.), Süsswasserflora von Mitteleuropa 19/2. Germany: Elsevier.

Komárek, J., \& Fott, B. (1983). Chlorophyceae, chlorococcales. In G. Huber-Pestalozzi (Ed.), Das Phytoplankton des Sdwasswes. Die Binnenggewasser, Vol. 16(5)'. Germany: Schweizerbart'sche Verlagsbuchhandlung.

Komárek, J., \& Johansen, J. R. (2015). Coccoid cyanobacteria. In J. D. Wehr, R. G. Sheath, \& R. P. Kociolek (Eds.), Freshwater algae from North America: ecology and classification (pp. 75-133). United Kingdom: Academic Press.

Krammer, K., \& Lange-Bertalot, H. (1991). Bacillariophyceae. 3. Teil Centrales, Fragilariaceae, Eunotiaceae. In H. Ettl, J. Gerloff, H. Heynig, \& D. Mollenhauer (Eds.), Süsswasserflora von Mitteleuropa. Germany: Gustav Fischer Verlag.

Kruk, C., \& Segura, A. M. (2012). The habitat template of phytoplankton morphology-based functional groups. Hydrobiologia, 698, 191-202.

Kruk, C., Huszar, V. L. M., Peeters, E. T. H. M., Bonilla, S., Costa, L., Lürling, M., Reynolds, C. S., \& Scheffer, M. (2010). A morphological classification capturing functional variation in phytoplankton. Freshwater Biology, 55, 614-627. 
Kruk, C., Devercelli, M., Huszar, V. L. M., Hernández, E., Beamud, G., Diaz, M., Silva, L. H. S., \& Segura, A. M. (2017). Classification of Reynolds phytoplankton functional groups using individual traits and machine learning techniques. Freshwater Biology, 62, 1681-1692.

Lee, R. D. (2008). Phycology. United Kingdom: Cambridge University Press.

Licursi, M., \& Gómez, N. (2002). Benthic in three diatoms and some environmental conditions lowland streams. Annales de Limnologie - International Journal of Limnology, 38, 109118.

Licursi, M., Gómez, N., \& Sabater, S. (2016). Effects of nutrient enrichment on epipelic diatom assemblages in a nutrient-rich lowland stream, Pampa Region, Argentina. Hydrobiologia, 766, 135-150.

Loez, C., \& Salibián, A. (1990). Premieres données sur le phytoplancton et les caractéristiques physico-chimiques de río Reconquista (Buenos Aires, Argentine): une riviere urbaine pollué. Revue du Hydrobiologie Tropicale, 23, 283-296.

Malmqvist, B., \& Rund, S. (2002). Threats to the running water ecosystems of the world. Environmental Conservation, 29, 134-153.

Meichtry de Zaburlín, N., Vogler, R. E., Molina, M. J., \& Llanao, V. M. (2016). Potential distribution of the invasive freshwater dinoflagellate Ceratium furcoides (Levander) Langhans (Dinophyta) in South America. Journal of Phycology, 52, 200-208.

Mischke, U., Venohr, M., \& Behrent, H. (2011). Using phytoplankton to assess the trophic status of German rivers. International Review of Hydrobiology, 96, 578-598.

Nõges, P., Mischke, U., Laugaste, R., \& Solimini, A. G. (2010). Analysis of changes over 44 years in the phytoplankton of Lake Vo rtsjärv (Estonia): the effect of nutrients, climate and the investigator on phytoplankton-based water quality indices. Hydrobiologia, 646, 33-48.

O’Farrell, I., Lombardo, R. J., de Tezanos Pinto, P., \& Loez, C. (2002). The assessment of water quality in the Lower Luján River (Buenos Aires, Argentina): phytoplankton and algal bioassays. Environmental Pollution, 120, 207-218.

Padisák, J., Borics, G., Grigorszky, I., \& Soróczki-Pintér, E. (2006). Use of phytoplankton assemblages for monitoring ecological status of lakes within the Water Framework Directive: the assemblage index. Hydrobiologia, 553, 1-14.

Padisák, J., Crossetti, L. O., \& Naselli-Flores, L. (2009). Use and misuse in the application of the phytoplankton functional classification: a critical review with updates. Hydrobiologia, $621,1-19$.

Pavé, P. J., \& Marchese, M. (2005). Invertebrados bentónicos como indicadores de calidad del agua en ríos urbanos (Paraná-Entre Ríos, Argentina). Ecología Austral, 15, 183197.

Phillips, G., Pietiläinen, O. P., Carvalho, L., Solimini, A., Lyche Solheim, A., \& Cardoso, A. C. (2008). Chlorophyll-nutrient relationships of different lake types using a large European dataset. Aquatic Ecology, 42, 213-226.

Piirsoo, K., Pall, P., Tuvikene, A., \& Viik, M. (2008). Temporal and spatial patterns of phytoplankton in a temperate lowland river (Emajogi, Estonia). Journal of Plankton Research, 30, 1285-1295.
Prygiel, J., \& Coste, M. (2000). Guide méthodologique pour la mise en oeuvre de l'Indice Biologique Diatomées. France: Agences de l'eau.

Reynolds, C. S. (1994). The long, the short and the stalled: on the attributes of phytoplankton selected by physical mixing in lakes and rivers. Hydrobiologia, 289, 9-21.

Reynolds, C. (2006). Ecology of Phytoplankton. United Kingdom: University Press.

Reynolds, C. S., Huszar, V., Kruk, C., Naselli-Flores, L., \& Melo, S. (2002). Towards a functional classification of the freshwater phytoplankton. Journal of Plankton Research, 24, 417428.

Reynolds, C. S., Mberly, S. C., Parker, J. E., \& De Ville, M. M. (2012). Forty years of monitoring water quality in Grasmere (English Lake District): separating the effects of enrichment by treated sewage and hydraulic flushing on phytoplankton ecology. Freshwater Biology, 57, 384-399.

Rodrigues Capítulo, A., Gómez, N., Giorgi, A., \& Feijoó, C. (2010). Global changes in pampean lowland streams (Argentina): implications for biodiversity and functioning. Hydrobiologia, 657, 53-70.

Sabater, S. (2008). Alterations of the global water cycles and their effects on river structure, function and services. Freshwater Reviews, 1, 75-88.

Salmaso, N., \& Padisák, J. (2007). Morpho-functional groups and phytoplankton development in two deep lakes (Lake Garda, Italy and Lake Stechlin, Germany). Hydrobiologia, 578, 97112.

Soares, M. C. S., Huszar, V. L. M., \& Roland, F. (2007). Phytoplankton dynamics in two tropical rivers with different degrees of human impact (southern Brazil). River Research and Applications, 23, 698-714.

Srebotnjak, T., Carr, G., de Sherbininc, A., \& Rickwood, C. (2012). A global water quality index and hot-deck imputation of missing data. Ecological Indicators, 17, 108-119.

Stanković, I., Vlahović, T., Gligora Udovič, M., Várbíró, G., \& Borics, G. (2012). Phytoplankton functional and morphofunctional approach in large floodplain rivers. Hydrobiologia, 698, 217-231.

Tejerina-Garro, F. L., Maldonado, M., Ibañez, C., Pont, D., Roset, N., \& Oberdorff, T. (2005). Effects of natural and anthropogenic environmental changes on riverine fish assemblages: a framework for ecological assessment of rivers. Brazilian Archives of Biology and Technology, 48, 91-108.

Tell, G., \& Conforti, V. (1986). Euglenophyta pigmentadas de Argentina. Bibliotheca Phycologica, 75, 1-301.

ter Braak, C. J., \& Šmilauer, P. (2012). Canoco reference manual and user's guide: software for ordination, version 5.0. Ithaca: Microcomputer Power.

Thackeray, S. J., Nõges, P., Dunbarc, M. J., Dudleyd, B. J., et al. (2013). Quantifying uncertainties in biologically-based water quality assessment: a pan-European analysis of lake phytoplankton community metrics. Ecological Indicators, 29, 34 47.

UNESCO (2006). Evaluación de los Recursos Hidricos. Elaboración del balance hídrico integral por cuencas hidrográficas. Documentos Técnicos del PHI-LAC, $\mathrm{N}^{\circ} 4$.

United Nations Environment Program (UNEP). (2002). Global environmental outlook 3: past, present and future perspectives. London: Earthscan Publications. 
Utermöhl, H. (1958). Zur Vervollkommnung der quantitative Phytoplankton: methodik. Mitt Int Verein Theor Angew, 9, $1-38$.

Venrick, E. L. (1978). How many cells to count? In A. Sournia (Ed.), Phytoplankton manual. Paris: UNESCO.

Wang, C., B-Béres, V., Stenger-Kovács, C., Li, X., \& Abonyi, A. (2018). Enhanced ecological indication based on combined planktic and benthic functional approaches in large river phytoplankton ecology. Hydrobiologia, 818, 163-175. https://doi.org/10.1007/s10750-018-3604-1.

Wilson, M.G. (2017). wManual de indicadores de calidad del suelo para las ecorregiones de Argentina. Ediciones INTA. Available in: https://inta.gob.ar.
Zalocar de Domitrovic, Y., \& Maidana, N. I. (1997). Taxonomic and ecological studies of the Parana River diatom flora (Argentina). In F. Lange-Bertalot \& P. Kociolek (Eds.), Bibliotheca Diatomologica. Berlin: J. Cramer.

Zar, J. H. (1996). Biostatistical analysis. New York: Prentice Hall $918 \mathrm{p}$.

Publisher's note Springer Nature remains neutral with regard to jurisdictional claims in published maps and institutional affiliations. 